\title{
NEW INSECTICIDAL METABOLITES FROM SOIL ISOLATE W719
}

\author{
Kalakota Reddy ${ }^{\dagger}$, Gary JewetT ${ }^{\dagger}$, Raymond Fatig, III, Michael Brockman, \\ Chris Hatton $^{\dagger \dagger}$, Phil Savickas ${ }^{\dagger \dagger}$, Dennis Hasha ${ }^{\dagger \dagger}$ and Carl SniPes \\ Fermentation Products, DowElanco, \\ P. O. Box 708, Greenfield, IN 46140, U.S.A. \\ ${ }^{\dagger \dagger}$ Instrumental Analysis, The Dow Chemical Company, \\ Midland, MI 48674, U.S.A. \\ ${ }^{\dagger+}$ Insecticide Discovery, DowElanco Company, \\ 2800 Mitchell Drive, Walnut Creek, CA 94598, U.S.A. \\ (Received for publication March 11, 1991)
}

\begin{abstract}
In the course of screening soil organisms for new insecticidal metabolites, strain W719 was found to produce a group of metabolites active against the tobacco budworm Heliothis virescens. The active metabolites were purified by a combination of solvent partitioning and chromatographic steps, and the physico-chemical properties and insecticidal activity of the main components were determined. The two main components have MW's of 925 and 939 , appear to belong to the macrocyclic lactam family of natural products, and possess significant insecticidal activity.
\end{abstract}

In a program for the discovery of novel natural products for use in crop protection, a tobacco budworm (Heliothis virescens) laboratory diet feeding assay was established to screen for insecticidal metabolite production by 5,000 soil microorganism isolates. Among the actives was strain W719, which produced a complex of novel lipophilic insecticidal metabolites. The crude culture extract and purified complex demonstrated moderate residual contact activity in foliar assays against tobacco budworm and beet armyworm, Spodoptera exigua. This paper outlines the purification, spectroscopic properties, and insecticidal activity of these metabolites.

\section{Experimental}

Strain Isolation and Storage

Strains used in the insecticidal screening program were isolated at the laboratory of Dr. JERRY ENSIGN, University of Wisconsin, Madison on colloidal chitin agar with $50 \mu \mathrm{g} / \mathrm{ml}$ cycloheximide from various soil and rhizosphere samples ${ }^{1)}$. Strain W719 was not speciated, but is presumed to be a strain of Streptomyces. The strain was subcultured on Oatmeal agar (Difco) with cycloheximide at $50 \mu \mathrm{g} / \mathrm{ml}$ and passaged at $28^{\circ} \mathrm{C}$. Freezer stock cultures were made by suspending whole cultures or spore preparations from agar slants in $10 \%$ glycerol, flash freezing, and storing at $-70^{\circ} \mathrm{C}$.

\section{Cultivation}

The 7 day growth of a $15-\mathrm{ml}$ oatmeal agar slant $(50 \mu \mathrm{g} / \mathrm{ml}$ cycloheximide $)$ was suspended in $5 \mathrm{ml}$ sterile deionized water, heat shocked at $45^{\circ} \mathrm{C}$ for 10 minutes $^{1)}$, and used to inoculate 10 new $15 \mathrm{ml}$ slants, one $100 \mathrm{ml}$ slant, or one $500-\mathrm{ml}$ tribaffled flask with a loose fitting plastic cap containing $150 \mathrm{ml}$ of medium (glucose $10 \mathrm{~g}$, soluble starch $20 \mathrm{~g}$, Amber EHC (Amber Laboratories, Milwaukee, Wisconsin) $2 \mathrm{~g}$, Bacto-casitone $2 \mathrm{~g}$, Bacto-yeast extract $2 \mathrm{~g}$ and Bacto-beef extract $2 \mathrm{~g}, \mathrm{CaCO}_{3} 3 \mathrm{~g}$, and deionized $\mathrm{H}_{2} \mathrm{O}$ $1,000 \mathrm{ml}$ ). Flasks were incubated at $28^{\circ} \mathrm{C}$ with shaking at $150 \mathrm{rpm}$ in a $\mathrm{G} 25 \mathrm{New}$ Brunswick platform shaker. For screening, $10 \mathrm{ml}$ whole culture samples were taken at days $3.5,5$ and 7 , lyophilized, and tested

$\dagger$ Present address: The Dow Chemical Company, 677 Building, Midland, MI 48674, U.S.A. 
by diet incorporation bioassay against the tobacco budworm. Multi-liter productions were started by the inoculation of $100 \mathrm{ml}$ oatmeal agar slants. Larger productions were grown in $500-\mathrm{ml}$ production medium in 2.8-liter modified Fernback flask (tribaffled and curved bottom) with a Shin-etsu silicone closure and inoculated with $100 \mathrm{ml}$ slants. A time course with analysis of production by bioassay and TLC showed day 3.5 to be the optimum harvest point. New Brunswick 10 liter fermenter productions were grown in the same medium, $28^{\circ} \mathrm{C}, 300 \mathrm{rpm}$ agitation, 6 liters/minute air, $\mathrm{pH}$ control either with $\mathrm{CaCO}_{3}$ or by the addition of $1.0 \mathrm{~N} \mathrm{NaOH}$ to maintain the $\mathrm{pH}$ above 6.0 , and a harvest time of 2.5 days.

\section{Instrumental Methods}

Mass spectra were obtained on a VG ZAB mass spectrometer operating in the FAB ionization mode. Positive and negative ion mass spectra were scanned from 1,100 to 100 daltons at 10 seconds/decade. Magic bullet and glycerol were used as dispersant agents. Accurate mass analysis were performed at 6,000 resolution by manual calibration of linear voltage scans across the molecular ion regions for the samples to which has been added a similar amount of PEG-600 as an internal mass marker. TLC was performed with Merck silica gel $60 \mathrm{~F}_{254}$ precoated glass plates and the spots were visualized with $10 \%$ isopropanolic solution of phosphomolybdic acid. UV spectra were recorded on a Cary 15 Spectrophotometer, IR spectra were recorded on Perkin-Elmer 983 Grating Spectrophotometer. ${ }^{1} \mathrm{H}$ NMR was recorded on IBM 300 AF $\left(300 \mathrm{MHz}\right.$ ) spectrometer and ${ }^{13} \mathrm{C}$ NMR spectrum was recorded on the IBM $300 \mathrm{AF}$ spectrometer operating at $75 \mathrm{MHz}$.

\section{Isolation and Purification}

The isolation and purification procedure of the active metabolites is shown in Scheme 1. The activity in a fermentation of strain W719 was found to be on the cell mass. The culture broth (10 liters) was centrifuged in 1 liter polypropylene bottles at $2,000 \times g$ to separate the mycelium from the broth. The mycelium was extracted with methanol, and the extract was evaporated to a dark green aqueous slurry in vacuo. Analytical samples were taken and found to be active against Heliothis virescens (see Table 1). The remaining extract was diluted with water and extracted three times with dichloromethane. The combined dichloromethane extract was dried over sodium sulfate and evaporated in vacuo to give a dark green residue $(250 \mathrm{mg})$. The dichloromethane extract was found to be active and was a very complex mixture

Scheme 1. Isolation and purification of active components from culture W719.

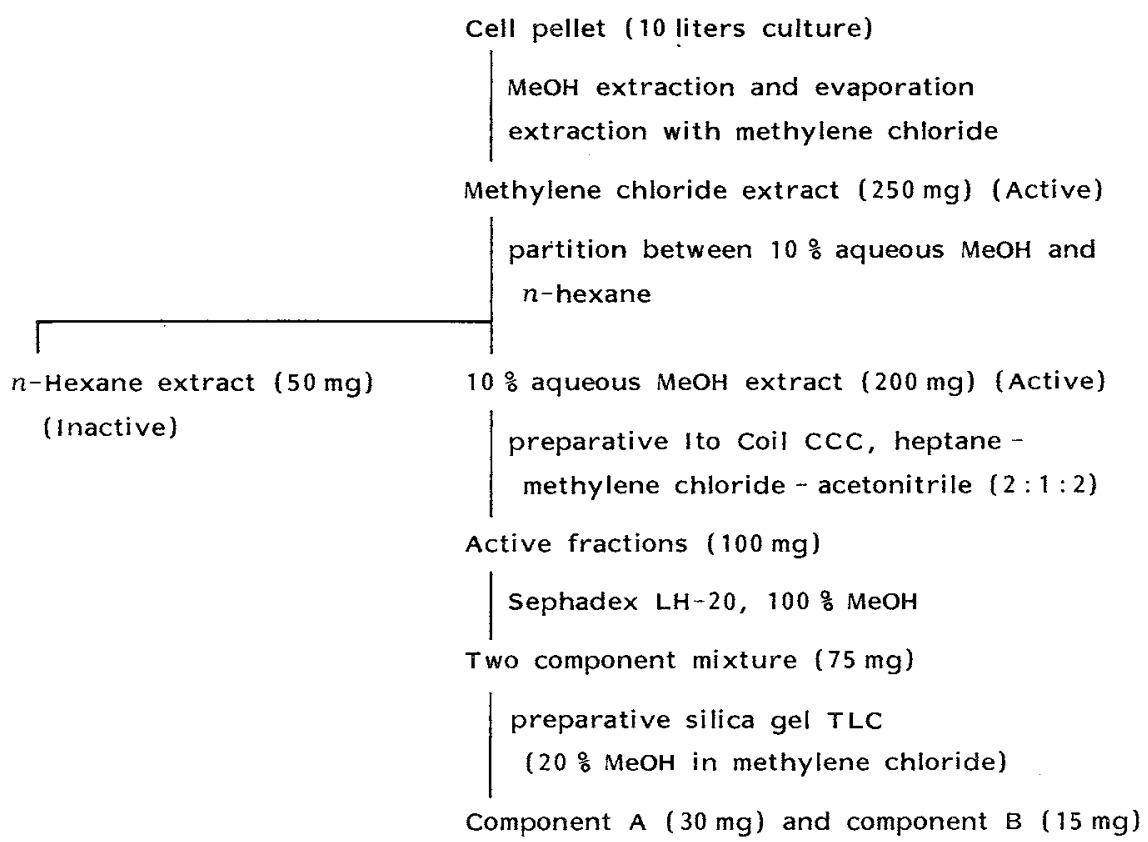


both on TLC and HPLC. The dichloromethane extract was partitioned between $n$-hexane and $10 \%$ aqueous methanol. The active aqueous methanolic extract $(200 \mathrm{mg})$ was subjected to liquid-liquid partition chromatography using an Ito Multi-Layer Coil Apparatus (P.C. Inc., centrifugal counter current chromatography), using the lower phase of heptane - dichloromethane-acetonitrile $(2: 1: 2)$ mixture as a mobile phase. The active fractions obtained were combined and concentrated to dryness affording a pale green residue $(100 \mathrm{mg})$. This residue was chromatographed over a $3.2 \times 120 \mathrm{~cm}$ Sephadex $\mathrm{LH}-20$ column using methanol as the eluting solvent. The active fractions from the Sephadex LH-20 column were combined and showed one major spot and one minor spot on silica gel TLC. Silica gel preparative TLC (20\% methanol in dichloromethane) gave two pure compounds, component $\mathrm{A}(30 \mathrm{mg})$ and component $\mathrm{B}(15 \mathrm{mg})$.

\section{Component A}

Colorless waxy solid, UV (1\% solution in MeOH), $\lambda_{\max } \mathrm{nm} 215$; IR $(\mathrm{KBr}) \mathrm{cm}^{-1} 3455(-\mathrm{OH}), 2970 \sim$ $2920(\mathrm{br}), 2700,1716(-\mathrm{C}=\mathrm{O}), 1668(\alpha, \beta$-unsaturated carbonyl), $1200 \sim 1000(-\mathrm{C}-\mathrm{O}-\mathrm{C}), 970(-\mathrm{CH}=$ $\mathrm{CH}-) ;{ }^{13} \mathrm{C}$ NMR $\left(\mathrm{CDCl}_{3}\right) \delta 148.7,133.5,129.2,119.3,106.1,98.4,98.2,85.8,81.6,79.5,74.7,74.6,74.4$, $72.2,69.6,68.1,67.8,67.1,61.8,54.2,43.2,41.4,39.9,38.3,35.6,35.3,34.5,30.6,30.3,30.2,29.6,29.1$, $29.0,28.7,28.6,26.8,23.5,22.1,19.9,13.4,11.3,10.0,6.0,5.5$; Mass spectrum $(\mathrm{m} / \mathrm{z})(\mathrm{FAB}$, glycerol): 927 $(\mathrm{M}+1), 909\left(\mathrm{M}-\mathrm{H}_{2} \mathrm{O}\right), 893,879,829,\left(\mathrm{M}^{+}\right.$measured 926.6159, $\mathrm{C}_{50} \mathrm{H}_{88} \mathrm{NO}_{14}$ calcd 926.6205$)$.

Component $B$ is structurally related to component $A$ as indicated by its very similar UV and NMR spectra, but its HR mass spectrum indicated that it has a MW 14 amu higher than component A, suggesting that it may be a methyl ether of component A. Structure elucidation of these two new insecticides will be published elsewhere.

\section{Insect Assays}

The diet incorporation assay for activity against the tobacco budworm was used for screening broths and following activity during isolation procedures. The sample was dissolved in water or acetone and mixed with $3 \mathrm{ml}$ of laboratory diet in a $20-\mathrm{ml}$ vial. One or two second instar larvae were placed in each vial and mortality was recorded after 5 days. Topical activity against tobacco budworm was measured by applying $1 \mu \mathrm{l}$ of an acetone solution of the sample to the anterior one-third of five 50-mg larvae. Injection activity against tobacco budworm was measured by injecting $0.5 \mu \mathrm{l}$ of an acetone solution of the sample laterally into the posterior one-third of five $35-\mathrm{mg}$ larvae. For both topical and injection assays, larvae were maintained separately in $35 \mathrm{~mm}$ plastic Petri dishes containing laboratory diet, and mortality was determined at 24 hours after treatment and confirmed 3 days after treatment. Foliar tests were performed by dipping the well-expanded first or second true leaves of cotton plants into an aqueous solution or detergent suspension of the test material, and allowing the leaves to dry. For tobacco budworm assays, ten 33-mm discs were cut from the leaves and placed in $35 \mathrm{~mm}$ Petri dishes with one second instar larva per dish. For beet armyworm, two whole leaves from which the edges had been trimmed were placed in $85 \mathrm{~mm}$ Petri dishes with five second instar larvae. For two-spotted spider mite (Tetranychus urticae), $33 \mathrm{~mm}$ leaf discs were placed in the center of moist $55 \mathrm{~mm}$ Whatman No.1 filter paper discs on top of $125 \mathrm{ml}$ plastic specimen containers filled with water, and 10 to 15 insects were applied to each disc. Mortality was determined at 24 hours and confirmed at 3 days. Cotton aphid (Aphis gossypii) activity was measured by infesting cotton plants at the first true leaf stage before dipping the leaves into the test material. The infested and treated plants were maintained in the greenhouse and mortality was measured 3 or 4 days after treatment. Test material applications for residual contact activity against tobacco budworm and beet armyworm were as described above. The plants then were incubated in the greenhouse and were placed outside in direct sunlight for 4 hours each day. Leaves were removed from plants for infestation at times after treament as indicated in Table 3. Mortality in all experiments was corrected for mortality in the controls by application of ABBOTT's formula ${ }^{2}$.

\section{Results and Discussion}

The methanolic extract of the cell pellets of Streptomyces W719 showed significant insecticidal activity when tested against $H$. virescens. As shown in Scheme 1, the isolation of two active components was guided 
Fig. 1. IR spectrum of component $\mathrm{A}(\mathrm{KBr})$.

(\%)

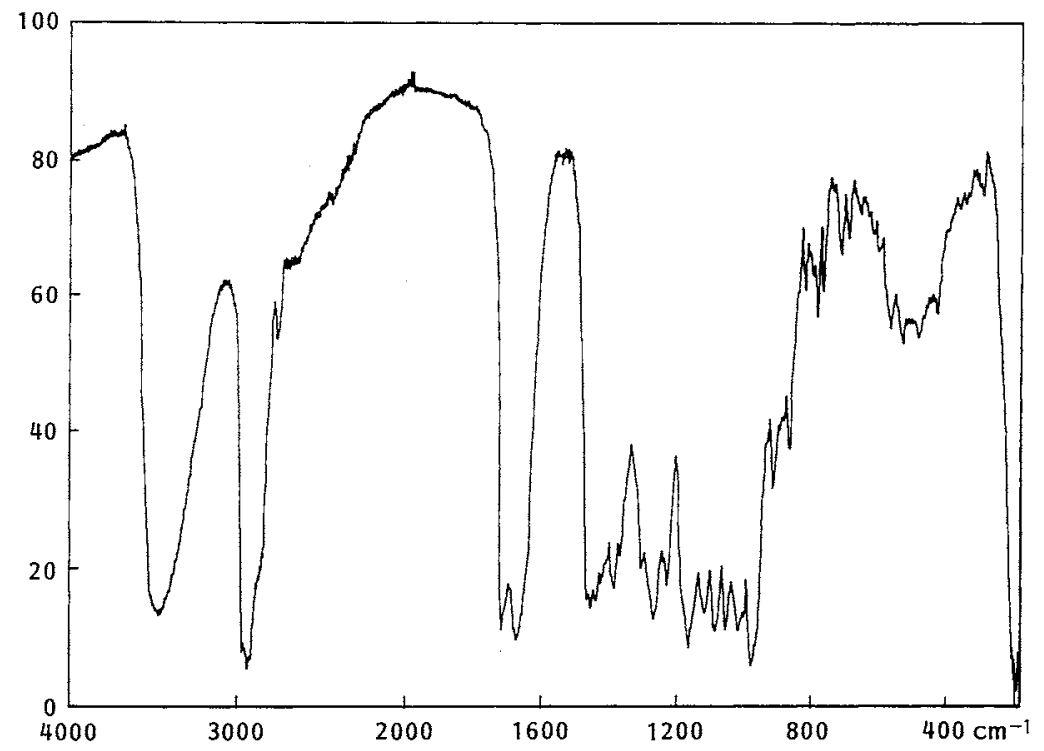

Fig. 2. ${ }^{1} \mathrm{H}$ NMR spectrum of component $\mathrm{A}\left(300 \mathrm{MHz}, \mathrm{CDCl}_{3}\right)$.

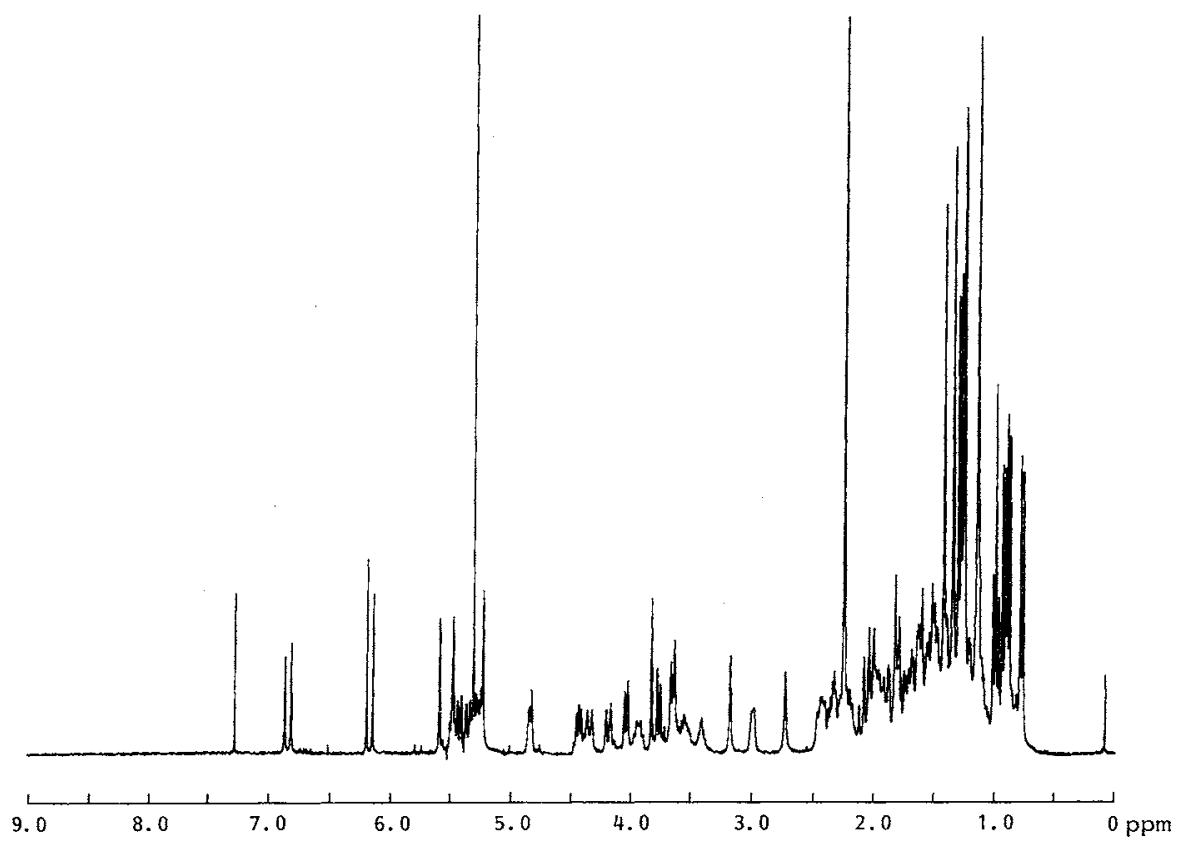

by diet-cup, topical or injection insecticidal bioassay and the activity was accomplished by three partitions, followed by size exclusion chromatography and preparative TLC.

Component $A$ was obtained as a colorless waxy solid. The IR spectrum of component $A$ showed broad bands at $3450 \mathrm{~cm}^{-1}$ (-OH stretchings), and 1716 and $1668 \mathrm{~cm}^{-1}$ indicated the presence of an 
Fig. 3. ${ }^{13} \mathrm{C}$ NMR spectrum of component $\mathrm{A}\left(75 \mathrm{MHz}, \mathrm{CDCl}_{3}\right)$.

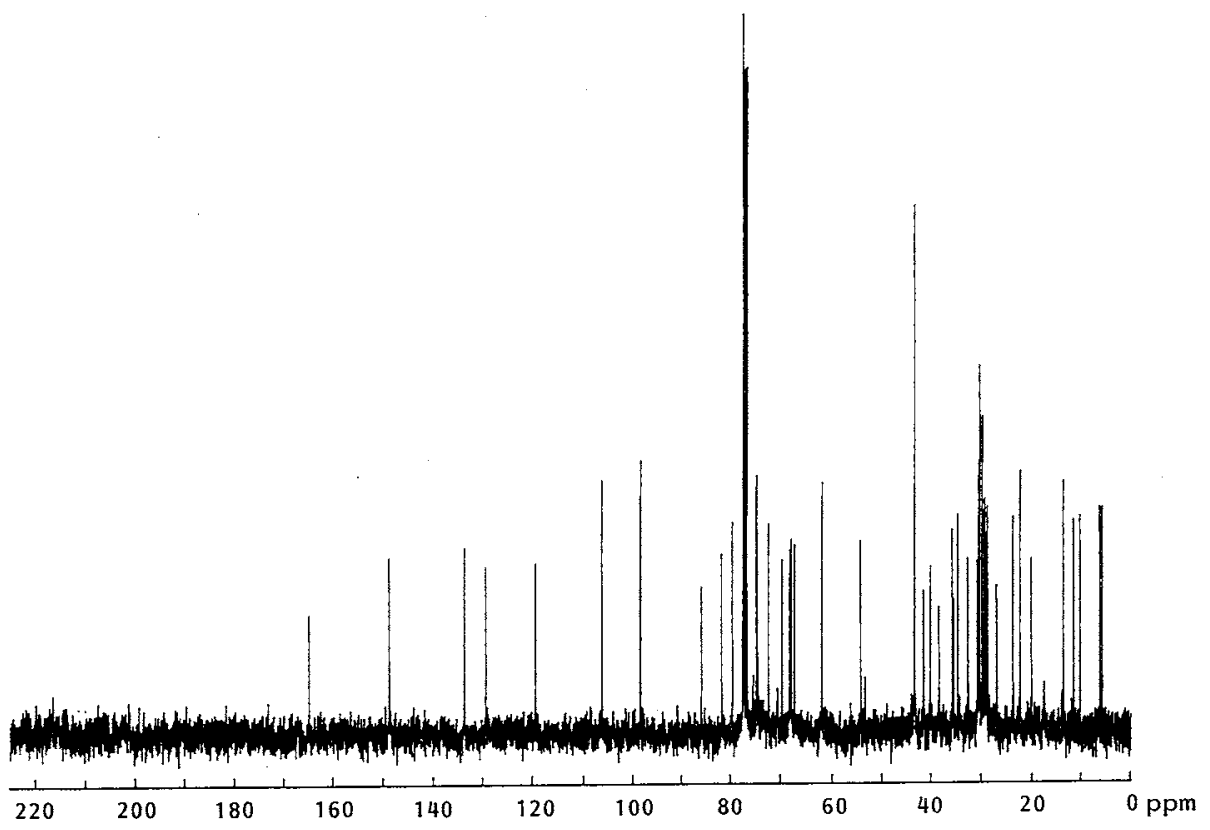

Fig. 4. Mass spectrum of component A (FAB).

(A) Positive ions, (B) negative ions.

(A)

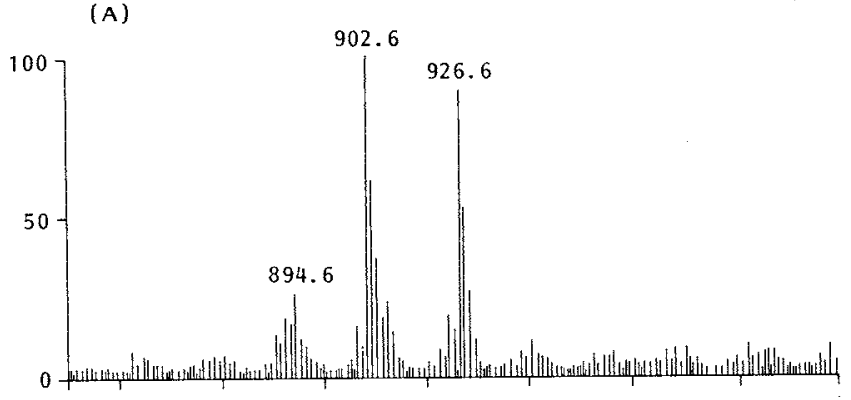

(B)

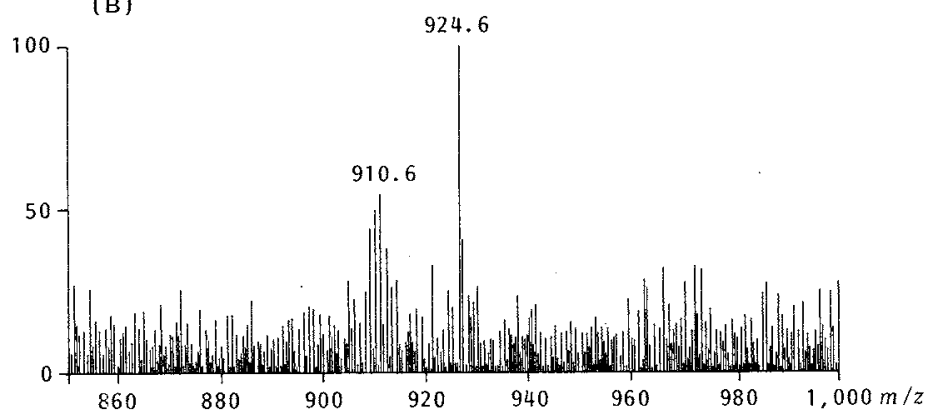


Table 1. Diet, injection, and topical insecticidal activity of W719 crude extract and pure metabolite complex.

\begin{tabular}{|c|c|c|c|}
\hline Test format & Sample & Test level & $\%$ Mortality \\
\hline \multicolumn{4}{|c|}{ Tobacco budworm diet incorporated: } \\
\hline One 2nd instar larva/vial & Crude extract & $30 \mathrm{ml} \mathrm{broth} /$ vial & 100 \\
\hline \multirow[t]{5}{*}{$3 \mathrm{ml}$ laboratory diet/vial } & (broth equiv) & $10 \mathrm{ml} \mathrm{broth/vial}$ & 100 \\
\hline & & $3 \mathrm{ml}$ broth/vial & $0 \mathrm{~s}$ \\
\hline & Pure complex & $20 \mu \mathrm{g} / \mathrm{vial}$ & $45 \mathrm{ss}$ \\
\hline & & $6.6 \mu \mathrm{g} / \mathrm{vial}$ & $11 \mathrm{~s}$ \\
\hline & & $2.2 \mu \mathrm{g} / \mathrm{vial}$ & 0 \\
\hline \multicolumn{4}{|l|}{ Injection: } \\
\hline $50 \mathrm{mg}$ larvae & Crude extract & $250 \mu 1 /$ larva & 100 \\
\hline \multirow[t]{9}{*}{ Sample in $0.5 \mu \mathrm{l}$ acetone } & (broth equiv) & $50 \mu 1 /$ larva & 100 \\
\hline & & $10 \mu 1 /$ larva & $0 \mathrm{~s}$ \\
\hline & Pure complex & $10.0 \mu \mathrm{g} /$ larva & 100 \\
\hline & & $3.3 \mu \mathrm{g} /$ larva & 100 \\
\hline & & $1.1 \mu \mathrm{g} /$ larva & 100 \\
\hline & & $0.37 \mu \mathrm{g} /$ larva & 75 \\
\hline & & $1.0 \mu \mathrm{g} /$ larva & 80 \\
\hline & & $0.33 \mu \mathrm{g} /$ larva & 20 \\
\hline & & $0.11 \mu \mathrm{g} /$ larva & 0 \\
\hline \multicolumn{4}{|l|}{ Tobacco budworm topical: } \\
\hline $50 \mathrm{mg}$ larvae & Crude extract & $500 \mu \mathrm{l}$ broth equiv & 0 \\
\hline \multirow[t]{4}{*}{ Sample in $1 \mu \mathrm{l}$ acetone } & Pure complex & $20 \mu \mathrm{g} /$ larva & $40 \mathrm{~s}$ \\
\hline & & $6.6 \mu \mathrm{g} /$ larva & 50 \\
\hline & & $2.2 \mu \mathrm{g} /$ larva & 40 \\
\hline & & $0.75 \mu \mathrm{g} /$ larva & 0 \\
\hline
\end{tabular}

s: Stunted, ss: severely stunted.

Table 2. Insecticidal activity of W719 samples in foliar greenhouse assays.

\begin{tabular}{|c|c|c|c|c|}
\hline \multirow{2}{*}{ Sample } & \multicolumn{4}{|c|}{$\%$ Mortality } \\
\hline & $\begin{array}{l}\text { Tobacco } \\
\text { budworm }\end{array}$ & $\begin{array}{c}\text { Beet } \\
\text { armyworm }\end{array}$ & $\begin{array}{c}\text { 2-Spotted } \\
\text { spider mite }\end{array}$ & $\begin{array}{l}\text { Cotton } \\
\text { aphid }\end{array}$ \\
\hline \multicolumn{5}{|l|}{ Crude extract: } \\
\hline $50 \times$ broth conc & $29 \mathrm{~s}$ & 100 & 25 & 35 \\
\hline $10 \times$ broth conc & 0 & 30 & 25 & 15 \\
\hline $2 \times$ broth conc & 0 & 0 & 11 & 0 \\
\hline \multicolumn{5}{|l|}{ Pure complex: } \\
\hline $500 \quad \mu \mathrm{g} / \mathrm{ml}$ & $90 \mathrm{ss}$ & 100 & 12 & 90 \\
\hline $167 \mu \mathrm{g} / \mathrm{ml}$ & 40 ss & $45 \mathrm{~s}$ & 0 & 12 \\
\hline $56 \mu \mathrm{g} / \mathrm{ml}$ & 0 & 0 & 0 & 0 \\
\hline \multicolumn{5}{|l|}{ Standard: } \\
\hline $100 \mu \mathrm{g} / \mathrm{ml}$ & $71 \mathrm{a}$ & $80 \mathrm{~b}$ & $81 \mathrm{c}$ & $100 \mathrm{~b}$ \\
\hline $25 \quad \mu \mathrm{g} / \mathrm{ml}$ & 29 & 0 & 45 & 100 \\
\hline $6.25 \mu \mathrm{g} / \mathrm{ml}$ & $0 \mathrm{~s}$ & 0 & 0 & 92 \\
\hline
\end{tabular}

a: Pydrin, b: chlorpyrofos, c: cyhexatin, s: stunted, ss: severely stunted.

$\alpha, \beta$-unsaturated amide functionality (Fig. 1). The high field ${ }^{1} \mathrm{H}$ NMR spectrum of component A was quite well resolved in the down field region between 5 and $7 \mathrm{ppm}$. However, the bulk of protons absorbed in the region $0.9 \sim 1.9$, indicated that component $\mathrm{A}$ was highly saturated (Fig. 2). The ${ }^{13} \mathrm{C}$ NMR indicated the presence of $5 s p^{2}$ carbons, 9 methyl groups, $13 \mathrm{CH}_{2}$-groups, and $20 \mathrm{CH}$-groups (Fig. 3). The HRFAB mass spectrum (Fig. 4) of component $\mathrm{A}$ showed a positive ion at $m / z 926.6205(\mathrm{M}+\mathrm{H})^{+}$which requires 
Table 3. Residual contact activity of W719 pure complex in foliar greenhouse tests with 4 hours direct sunlight exposure per day.

\begin{tabular}{|c|c|c|c|c|c|c|c|}
\hline \multirow{3}{*}{ Day after treatment } & \multicolumn{7}{|c|}{$\%$ Mortality } \\
\hline & \multicolumn{4}{|c|}{ Tobacco budworm } & \multicolumn{3}{|c|}{ Beet armyworm } \\
\hline & 0 & 1 & 2 & 4 & 0 & 1 & 2 \\
\hline \multicolumn{8}{|c|}{ W719 pure complex $(\mu \mathrm{g} / \mathrm{ml})$ : } \\
\hline 300 & 80 & 50 & 50 & $100 \mathrm{LK}$ & $\mathrm{nt}$ & 96 & 100 \\
\hline 100 & 10 & 30 & 0 & $55 \mathrm{LK}$ & $\mathrm{nt}$ & 76 & 72 \\
\hline 33 & 10 & 0 & 0 & $35 \mathrm{LK}$ & $\mathrm{nt}$ & 16 & 16 \\
\hline 11 & 0 & 0 & 0 & 0 & $\mathrm{nt}$ & 8 & 0 \\
\hline \multicolumn{8}{|l|}{ Pydrin $(\mu \mathrm{g} / \mathrm{ml})$ : } \\
\hline 100 & 100 & 90 & 60 & 50 & nt & 100 & 76 \\
\hline 25 & 20 & 20 & 0 & $50 \mathrm{LK}$ & $n t$ & 64 & 44 \\
\hline 6.25 & 0 & 0 & 0 & 0 & $\mathrm{nt}$ & 4 & 0 \\
\hline
\end{tabular}

nt: Not tested, LK: late kill with significant leaf damage.

the molecular formula $\mathrm{C}_{50} \mathrm{H}_{88} \mathrm{NO}_{14}$. The mass spectrum also showed a prominent peak at $\mathrm{m} / \mathrm{z} 909$ which is interpreted as the loss of one molecule of water. Based on the initial physico-chemical and spectral data, component A seemed to be a polyhydroxylated macrolide similar to cytovaricin ${ }^{3)}$, but containing an amide moiety.

The insecticidal activity of the W719 dichloromethane extract and pure complex (mixture of components $\mathrm{A}$ and $\mathrm{B}$ ) in diet, injection, and topical assays is summarized in Table 1. The activity in the extract compared to the pure complex is consistent with a broth production level of about $1 \mathrm{ppm}$. The stunting of growth observed at sublethal doses in the diet assay suggests an antifeedant effect. The relatively potent injection activity compared with the flat dose-response in the topical assay suggests that the compound either does not penetrate the cuticle well or is metabolized rapidly. Alternatively, the low activity seen in the topical assay could be due to ingestion of the cuticle after molting.

The activity in foliar greenhouse assays is presented in Table 2 . The metabolites are moderately active against beet armyworm and tobacco budworm, with weak activity against cotton aphids.

The residual contact activity data presented in Table 3 show that the metabolites retain approximately half their activity against tobacco budworm after 2 days with 4 hours sunlight per day, and show slightly better residual activity against beet ārmyworm.

\section{References}

1) Ensign, J. D.: Developmental biology of actinomycetes. In Overproduction of Microbial Products. Ed., V. Krumphanzl et al., pp. 127 140, Academic Press, 1982

2) Аввотт, W. S.: A Method of computing the effectiveness of an insecticide. J. Econ. Entomol. 18: $265 \sim 267,1925$

3) Kinara, T.; M. Ubukata, J. Uzawa \& K. Isono: Biosynthesis and ${ }^{13} \mathrm{C}$ NMR assignment of cytovaricin, a neutral macrolide antibiotic. J. Antibiotics 42: 919 925, 1989 